\title{
Cardiac Allograft Vasculopathy: An Ongoing Challenge in the Care of Heart Transplant Recipients
}

\author{
Brian Clarke and Kiran Khush \\ Division of Cardiovascular Medicine, Stanford University, Stanford, California,
} USA

\section{Introduction}

Cardiac allograft vasculopathy (CAV) represents the most common cause of late graft failure and limits the long-term success of heart transplantation. It is the most common cause of death, in addition to malignancy, in patients who survive the first year after transplant (Taylor et al., 2006). CAV is a diffuse, accelerated form of coronary artery disease in the transplanted heart. Despite improvements in immunotherapy, the incidence of angiographically detected CAV has not changed appreciably over the past two decades. CAV is associated with a relentless course after heart transplantation and immunological and non-immunological interventions have only partially modified its natural history. Treatment of CAV is limited, highlighting the importance of preventive therapies. Retransplantation for advanced disease is the only definitive therapy, but is limited to select patients. In this chapter, we will review the epidemiology, natural history, clinical manifestations, screening and diagnostic strategies for CAV while emphasizing current treatment strategies designed to prevent or slow the progression of this disease.

\section{Pathology}

CAV was first described in 1970 as a diffuse, obliterative, accelerated form of arteriosclerosis (Bieber et al., 1970). Pathologically, CAV is distinctly different from traditional coronary atherosclerosis (Table 1). It is characterized by diffuse, concentric intimal smooth muscle hyperplasia involving the entire circumference and length of the vessel, and deposition of neointima in the major epicardial vessels and microvasculature, which progressively obstructs the affected vessel lumen (Figure 1). CAV is further distinguished microscopically as having intense cellular proliferation, composed mainly of smooth muscle cells and inflammatory infiltrates (monocytes and lymphocytes). Specific populations of lymphocytes co-localized with CAV lesions include recipient CD4+ T cells, thus suggesting a role for major histocompatibility complex (MHC) II antigen recognition and processing in the development of CAV. Populations of macrophages and CD8+ T cells have also been localized in CAV lesions, whereas recipient B-cells are rare.

The endomyocardial biopsy has limited sensitivity in the recognition of vasculopathy because it samples only the smallest of intramyocardial arteries and arterioles, which often 
do not show histologic features of CAV. Reported histologic changes seen in the small arteries in endomyocardial biopsies include concentric intimal thickening with or without foamy macrophages, subendothelial accumulation of lymphocytes, and perivascular fibrosis (Pardo et al., 1997). Evidence of myocardial ischemia, such as myocytolysis, frank coagulation necrosis, and healing ischemic lesions as well as interstitial, perivascular, and replacement fibrosis can be seen (Neish et al., 1992). Identification of myocardial injury should raise the suspicion of CAV as the cause of graft dysfunction. The absence of these findings, however, does not necessarily rule out the presence of CAV.

\section{Pathogenesis}

The development of CAV represents a complex interaction between acute and chronic immune activation via an allo-immune pathway and alloantigen-independent non-immune mechanisms that ultimately lead to inflammation and endothelial injury, the precursor to CAV. (Figure 2). Immunologic events appear to be most important, since CAV develops in the donor's coronary arteries but not the recipient's vasculature. The donor coronary artery endothelial cells express major histocompatibility complex (MHC) class I and class II antigens, and thus appear to be primary targets of the cell-mediated and humoral immune responses. These antigens are thought to be recognized by recipient CD8+ and CD4+ T cells and these activated lymphocytes secrete cytokines (interleukins, interferons, and tumor necrosis factors), which promote proliferation and further activation of allo-reactive $\mathrm{T}$ cells, monocytes, and macrophages. Macrophages are then recruited to the intima where they elaborate cytokines (IL-1, IL-6, tumor necrosis factor TNF alpha) and growth factors [platelet derived growth factor (PDGF), insulin-like growth factor-I (IGF-I), transforming growth factor-alpha (TGF-alpha), TGF-beta-1], leading to smooth muscle cell proliferation and synthesis of extracellular matrix (Libby P \& Tanaka H, 1994).

$\mathrm{T}$ cell activation also stimulates the expression of adhesion molecules, [intercellular cell adhesion molecule-1 (ICAM-1), vascular cell adhesion molecule-1 (VCAM-1), P-selectin] thereby "activating" endothelial cells, enabling recruitment of proinflammatory cells from the vasculature and the initiation of the immune response and subsequent development of CAV. (Briscoe et al., 1995)

\begin{tabular}{lll}
\hline \hline Pathologic characteristic & CAV & Native CAD \\
\hline Lesion morphology & Diffuse, concentric (variable) & Focal, proximal, eccentric \\
Vessels involved & Intramyocardial, epicardial & $\begin{array}{l}\text { Epicardial, spares } \\
\text { intramyocardial branches }\end{array}$ \\
Collateral vessels & Minimal & Often extensive \\
Initial Lesion & Smooth muscle proliferation & Fatty streaks \\
Internal Elastic Lamina & Intact & Disrupted \\
Endothelial lymphocytes & Sometimes & Absent \\
T-cell location & Subendothelial & Edge of plaque \\
\hline \hline
\end{tabular}

Table 1. Characteristics of cardiac allograft vasculopathy compared to traditional coronary atherosclerosis in the native heart. 

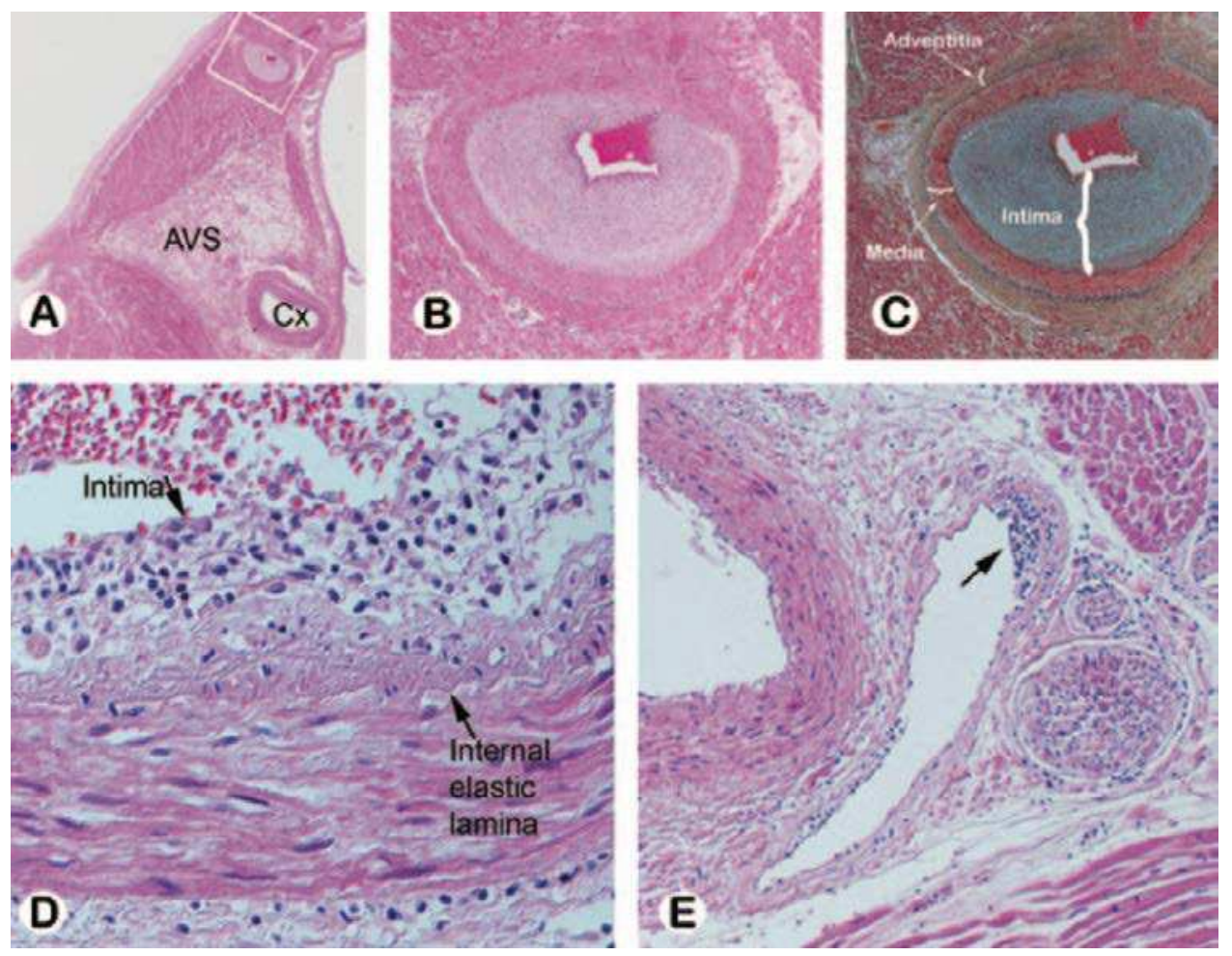

Fig. 1. Cardiac allograft vasculopathy. (A) Photomicrograph of the left atrium and ventricle with the left circumflex $(\mathrm{Cx})$ artery noted at the atrioventricular sulcus (AVS) from a patient who died of CAV 3 years post transplant. $(B, C)$ Intramyocardial branch of circumflex artery (from inset A) supplying the atrium shows marked intimal proliferation with preservation of the elastic lamina and normal medial layer (hematoxylin-eosin (B) and Movat pentachrome (C)). (D,E) Subendothelial lymphocytic infiltration is seen in a small epicardial artery (D) and in an intramyocardial vein (arrow E). Reprinted from Tan CD, Baldwin WM, Rodriguez ER. Update on Cardiac Transplantation Pathology. Arch Pathol Lab Med. 2007;131:1169-1191 with permission from Archives of Pathology and Laboratory Medicine. Copyright 2007. College of American Pathologists.

Non -immune mechanisms implicated in the development of CAV include inflammatory injury due to recipient hypertension, dyslipidemia, diabetes and insulin resistance, and obesity, in addition to ischemia-reperfusion injury during organ procurement. Endothelial cell dysfunction resulting from inflammatory injury predisposes to thrombosis, vasoconstriction, and vascular smooth muscle cell proliferation. Reperfusion injury increases expression of endothelin 1, which is associated with posttransplant ischemic fibrosis and subsequent development of arteriopathy, in addition to generating free radicals that promote the expression of such inflammatory adhesion molecules and subsequent leukocyte recruitment (Ferri et al., 2002). More research is needed in the field of organ preservation, possibly targeting specific cellular processes to minimize reperfusion injury. Endothelial injury and dysfunction, regardless of the 
mechanism, seems to be the key inciting event and the common pathway for the development of CAV.

\section{Risk factors}

Many risk factors for the development of CAV have been identified and can be broadly divided into donor-specific factors, recipient-specific factors and donor-recipient factors, with the latter being predominantly immune mediated (Table 1).

\subsection{Donor factors}

Donor factors include a history of hypertension, diabetes, male sex, and history of tobacco use. Older donor hearts confer a higher risk of CAV development compared to younger donor hearts, and this risk appears most significant with donors older than 50 years (AlKhaldi et al., 2006; Nagji et al., 2010).

Donor mode of death has also been shown to have associations with the development of CAV. Explosive modes of brain death, including gunshot wound to the head, accidental head trauma, or a rapidly progressive intracranial hemorrhage have also been associated with development of CAV after transplantation (Mehra et al., 2004a). It has been demonstrated that rapid brain death induces a calcium overflow injury that affects conduction tissue, coronary artery smooth muscle, and myocardial cells (Cohen et al., 2007; Novitzky et al., 1988). There is also a generalized activation of macrophage-associated cytokines, an up-regulation of immunoregulatory and adhesion cell molecules with subsequent endothelial inflammation and dysfunction, in addition to increased levels of circulating catecholamines, all of which may negatively impact the graft response after heart transplantation (Segel et al., 2002; Takada et al., 1998).

The role of transmitted native vessel atherosclerosis is controversial and conflicting. Studies utilizing serial coronary artery intravascular ultrasound (IVUS) found donor lesions did not significantly change after transplantation (Jimenez et al., 2001). However a maximal intimal thickness $\geq 0.5 \mathrm{~mm}$ at baseline ( 1 month post transplant) was one of the strongest predictors of plaque progression at one year in another study (Yamasaki et al., 2011). In another observational study, donor lesions (defined by intimal thickness $>0.5 \mathrm{~mm}$ by IVUS at 1 month post transplant) did not have a greater increase in intimal thickness compared to other sites without donor lesions, however the incidence of angiographically apparent CAV up to three years after transplant was higher in patients with donor transmitted lesions with no apparent effect on 3 year mortality (Li H et al., 2006).

Hepatitis $\mathrm{C}$ infection $(\mathrm{HCV})$ in donor hearts increases recipient mortality with mortality rates in one study of $16.9 \%$ at 1 year, $41.8 \%$ at 5 years, and $50.6 \%$ at 10 years, compared to recipients of hepatitis $\mathrm{C}$ negative donors who had $8.2 \%, 18.5 \%$, and $24.3 \%$ mortality, respectively (Gasink et al., 2006). Recipients with HCV-positive donor hearts were more likely to die secondary to CAV. Other studies also note higher rates of CAV in recipients of $\mathrm{HCV}+$ donor hearts, possibly related to $\mathrm{HCV}$ viremia in a significant proportion of these recipients; the exact mechanism however, is not completely understood (Haji et al., 2004). Hepatitis B seropositivity (HBV) has been correlated with increased rates of CAV. In one observational study, HBV seropositivity, defined as either the donor or recipient being hepatitis B core antibody positive, was associated with higher rates of CAV at 1 year 
compared to cases where neither the donor nor recipient were HBV seropositive (Haji SA et al., 2006).

\subsection{Recipient factors}

Recipient factors that are associated with the development of CAV include male sex, pretransplant ischemic heart disease, and higher body mass index (Costanzo et al., 1998; Taylor et al., 2007). Traditional cardiac risk factors in the recipient including hypertension, diabetes, dyslipidemia and smoking also increase the risk of developing CAV (Sanchez et al., 2008). Importantly, hypertension, dyslipidemia and diabetes are commonly induced post transplant as side effects of immunosuppressant therapy with calcineurin inhibitors and steroids. The prevalence of hypertension increases after transplant from $74.4 \%$ at one year to $98.5 \%$ at 10 years (Taylor et al., 2007). The incidence of diabetes after heart transplant ranges from $15 \%$ to $20 \%$ (Martinez-Dolz et al., 2005).

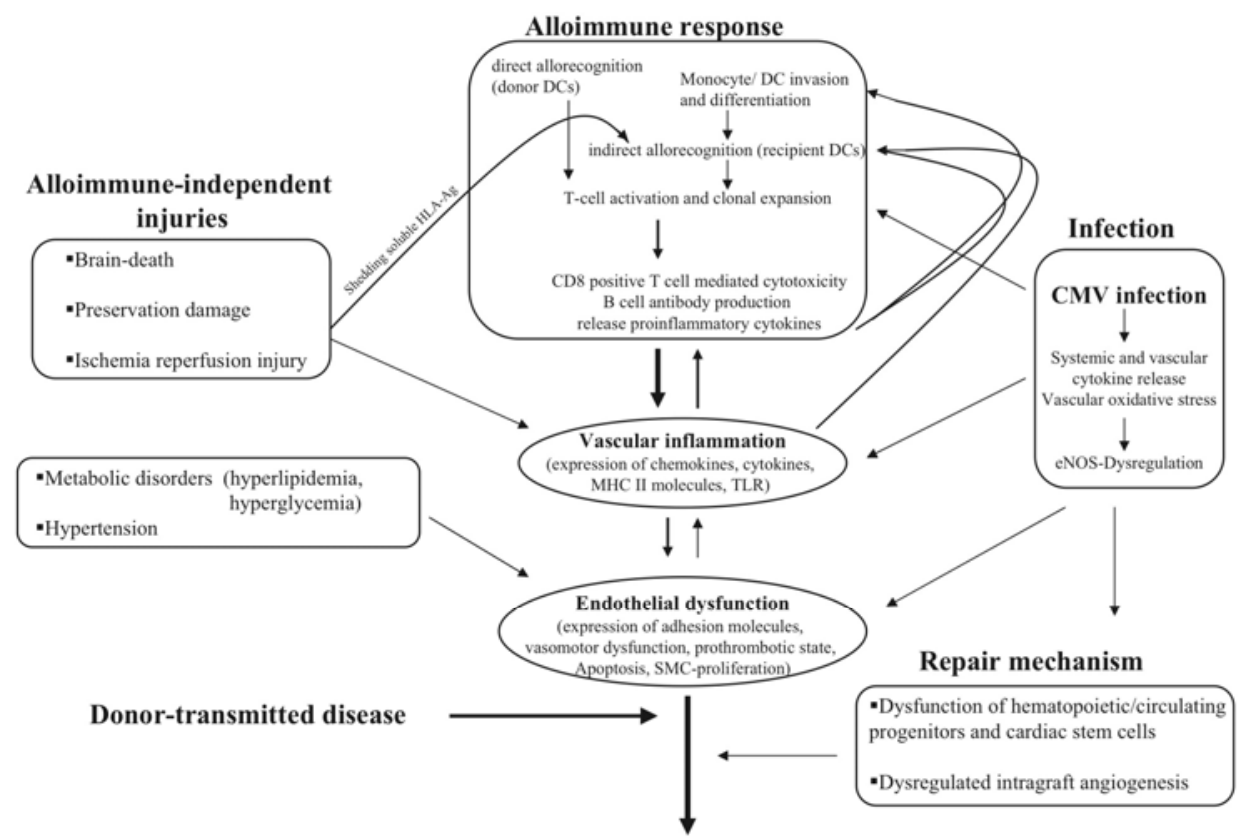

Transplant atherosclerosis

Fig. 2. Pathobiology of Cardiac Allograft Vasculopathy. Reprinted from Schmauss D and Weis M. Cardiac allograft vasculopathy: recent developments. Circulation 2008;117:21312141 with permission from Wolters Kluwer Health. Copyright 2008.

\subsection{Donor-recipient factors}

Donor-recipient factors that increase risk of CAV include episodes of high-grade cellular rejection during the first year after transplantation, HLA-DR mismatches, antibody mediated rejection (including asymptomatic AMR), and cytomegalovirus (CMV) infection. 
The total cellular rejection score at six months increases the risk of CAV by almost threefold (Raichlin et al., 2009). The total cellular rejection score is assigned based on ISHLT grading as $0 R=0,1 R=1,2 R=2,3 R=3$, and normalized by dividing the cumulative scores for the total number of biopsies taken during the 6 month intervals. Antibody-mediated rejection increases the incidence of CAV by $10 \%$ at one year and by $36 \%$ at five years (Michaels et al., 2003). Asymptomatic AMR, defined as histologic evidence of AMR, including endothelial swelling, interstitial hemorrhage, interstitial edema and neutrophil infiltration and/or immunoperoxidase staining showing CD-68 positive macrophages within capillary cells and C4d complement coating the walls of the myocardial capillaries, in patients without symptoms or any evidence of graft dysfunction, increases the risk of developing CAV compared to those with no AMR (We et al., 2009).

CMV disease appears to increase the risk of early-onset CAV -an effect that may be mediated via immune mechanisms rather than a direct consequence of the infective organism (Weill et al., 2001). CMV infection in endothelial cells, such as those lining the donor coronary arteries, leads to a local proinflammatory state and subsequent increased production of vascular cell adhesion molecule (VCAM)-1, alterations in cell surface MHC I and II molecules, and an increase in proinflammatory cytokines and growth factors. This causes endothelial cell/smooth muscle cell proliferation and narrowing of the vessel lumen. CMV may also cause endothelial dysfunction leading to CAV by impairing the nitric oxide synthase pathway. (Hosenpud et al., 2003; Koskinen 1993; Van Dorp et al., 1989). Nitric oxide prevents vascular inflammation and lesion formation in the vessel wall by inhibiting platelet and leukocyte adherence and by suppressing vascular smooth muscle cell proliferation. CMV infection of the endothelium increases expression of endothelial surface adhesion molecules and promotes mononuclear adhesion, activation, and transendothelial migration within the vasculature. In addition, CMV is a stimulus of plasma ADMA (asymmetric dimethylarginine) accumulation, the endogenous inhibitor of nitric oxide synthase. (Weis M et al., 2004)

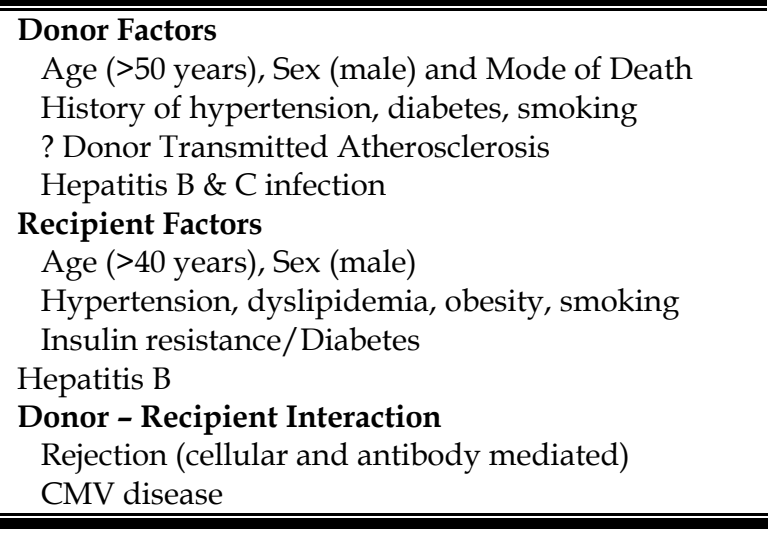

Table 2. Risk factors for the development of cardiac allograft vasculopathy

\section{Clinical manifestations}

Early CAV is clinically silent, and ischemia is usually not evident until the disease is far advanced. Patients are most often diagnosed by routine angiographic surveillance or loss of 
allograft function by surveillance imaging with negative rejection studies. Clinically, patients present with heart failure symptoms and are found to either have new onset systolic or diastolic dysfunction in the absence of acute cellular or antibody mediated rejection, or may present with ventricular arrhythmias and sudden cardiac death. Patients rarely present with chest pain, due to de-innervation of the cardiac allograft at the time of transplantation. However, $25-40 \%$ of patients develop some degree of re-innervation post transplant, manifest primarily by return of heart rate response and less often, ischemic chest pain (De Marco et al., 1995).

\section{Epidemiology and natural history}

CAV is detectable by coronary angiography in approximately $10 \%$ of heart transplant recipients within the first year, in $32 \%-50 \%$ by 5 years, and in an even greater number of recipients when detected by intravascular ultrasound (Pflugfelder et al., 1993). Once mild disease is identified angiographically, the likelihood of progression to severe CAV within 5 years is approximately 19\% (Costanzo et al., 1998). Lack of development of CAV at 1 year post-transplant identifies a group who are likely to remain free of clinical events through 6 years of follow up (Luyt et al., 2003). In patients with at least 1 focal stenosis $\geq 40 \%$, survival was $67 \%$ at 1 year, $44 \%$ at 2 years, and $17 \%$ at 5 years. With 3 vessels involved, survival was $13 \%$ at 2 years (Keogl et al., 1992). The overall likelihood of death or re-transplantation as a result of CAV is approximately $50 \%$ for severe CAV (Costanzo et al. 1998).

Graft function is an important component in evaluating severity of CAV. Patients with CAV and LV dysfunction have significantly lower 5-year survival compared with CAV patients without LV dysfunction (60\% vs. 90\%) (Stork et al., 2006). Patients with restrictive cardiac physiology [E to A velocity ratio $>2$, shortened isovolumetric relaxation time $(<60 \mathrm{msec})$, shortened deceleration time $(\leq 150 \mathrm{~ms})$, or restrictive hemodynamics (right atrial pressure $>12 \mathrm{mmHg}$, pulmonary capillary wedge pressure $>25 \mathrm{mmHg}$, cardiac index <2.0)] in the presence of preserved LV systolic function and CAV also have a lower 5-year survival than heart transplant patients without restrictive physiology (Itagaki et al., 2007).

\section{Diagnosis}

Coronary angiography and assessment of cardiac allograft function remains the cornerstone for diagnosis of CAV. Anatomic abnormalities characteristic of CAV include gradual, distal, diffuse, concentric tapering ("distal pruning") of the major epicardial arteries with obliteration of the small branching vessels. Discrete epicardial stenoses are less likely (Figure 3). As early CAV is asymptomatic, routine screening with annual coronary angiography (with or without intravascular ultrasound) is standard practice among the majority of transplant centers in the first 3-5 years post transplant. After this time period, there are different practice patterns for assessment of CAV, depending on individuals' risk factor profile for CAV, graft function, renal function, and clinical status. As CAV is a concentric process, early disease may be overlooked if prior angiograms are not compared. For this reason, baseline angiography is usually performed 4-6 weeks post transplant.

In 2010, the ISHLT working group proposed standardized nomenclature for CAV (Table 3) (Mehra et al., 2010). This system defined CAV as not significant, mild, moderate, and severe based on angiographic appearance. Angiography is a very useful test for detecting lesions 

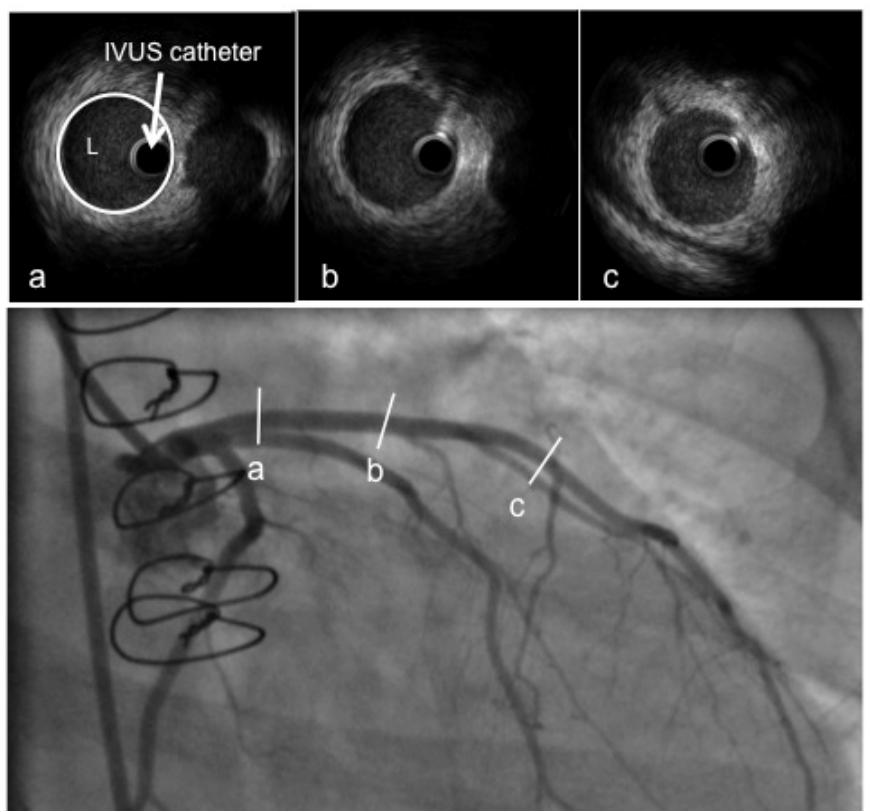

(A)
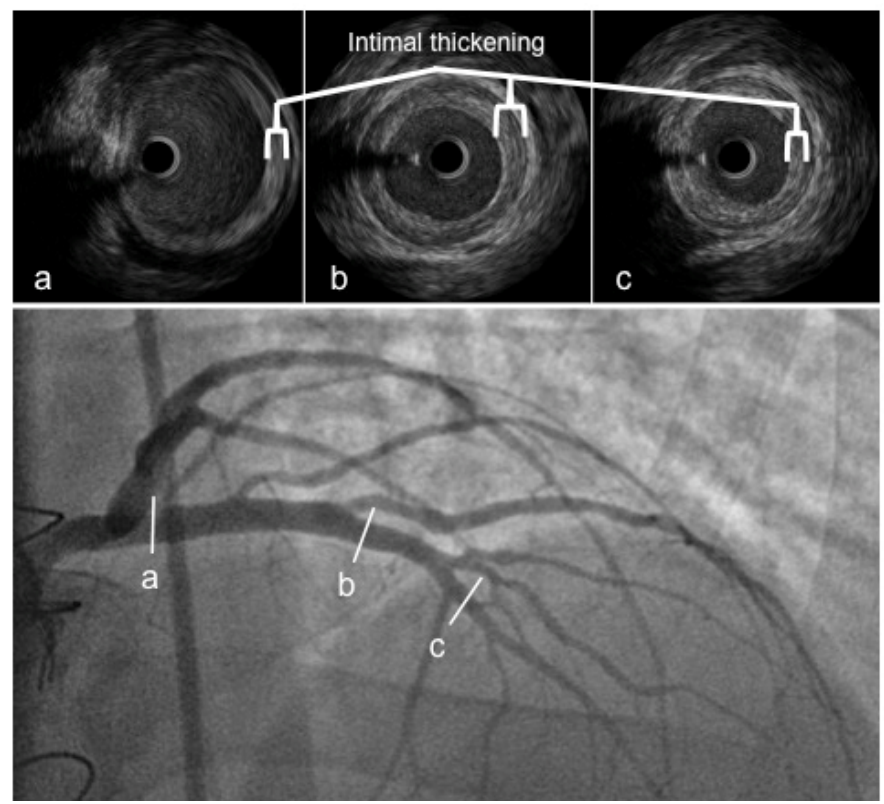

(B)

Fig. 3. Angiography and IVUS imaging demonstrating (A) normal coronary arteries and (B) cardiac allograft vasculopathy. ( $\mathrm{L}=$ coronary artery lumen). 
located in epicardial arteries and the main branches, however the main limitation of angiography is low sensitivity, especially in those mild cases in which an apparently normal examination can underestimate the presence of CAV. This is primarily due the vascular remodeling that occurs early in the disease in which there is no compromise in luminal diameter (Nissen 2001). Repeated angiography is recommended for the follow-up of patients with moderate lesions or for patients with symptoms leading to the suspicion of CAV.

Intra-vascular ultrasound (IVUS) at coronary angiography has been evaluated as an adjunctive modality for assessing and diagnosing early CAV. Angiography depicts only a 2dimensional silhouette of the lumen whereas IVUS allows a reproducible view of both actual lumen diameter, as well as the appearance and thickness of the intima and media. As the intima begins to thicken, the vessel area enlarges as a compensatory mechanism to preserve luminal area. Therefore, 'angiographically normal' coronary arteries may in fact have significant CAV.

IVUS parameters include intimal thickness, intimal index, and change in maximal intimal thickness at a reference point, total atheroma volume, and percentage of atheroma volume. IVUS can detect occult disease in angiographically normal sites and has emerged as the optimal diagnostic tool for early detection. CAV is considered present when the intimal thickness is $>0.3 \mathrm{~mm}$ (Rickenbacher et al., 1995). The presence of moderate to severe intimal thickening by IVUS is predictive of the future development of angiographically apparent CAV. IVUS-detected maximal intimal thickness (MIT) greater than $0.3 \mathrm{~mm}$ at 1 year is associated with a 4 -year actuarial survival of $73 \%$ versus $96 \%$ among those with less than $0.3 \mathrm{~mm}$ of intimal thickening (Rickenbacher et al., 1995). A change in MIT of $\geq 0.5 \mathrm{~mm}$ at a specific site in the coronary tree within the first year after transplant predicts outcomes at 5 years related to the development of angiographic CAV, mortality and myocardial infarction (Kobashigawa et al., 2005; Tuzcu et al., 2005). Death or graft loss occurred in $21 \%$ versus $6 \%$, non-fatal major adverse events or death/graft loss in $46 \%$ versus $17 \%$ and angiographically apparent disease in $65 \%$ versus $33 \%$ in those with a change in MIT $\geq 0.5 \mathrm{~mm}$ between baseline and 1-year (Kobashigawa et al., 2005) versus those with a lesser degree of intimal thickening. With $>0.6 \mathrm{~mm}$ intimal thickening, patients are 10 times more likely to experience a cardiac event and for those who developed cardiac events, $62 \%$ of patients had 'normal' angiograms (Mehra et al., 1995).

In patients with stable graft function and no history of $\mathrm{CAV}$, most centers alternate coronary angiography with dobutamine stress echocardiography after 3-5 years; reserving invasive catheterization to every other year. The sensitivity and specificity of dobutamine stress echocardiography compared with coronary angiography and IVUS for detecting CAV is approximately $80 \%$ and $88 \%$ respectively (Derumeaux et al., 1995; Spes et al., 1999). A normal DSE incorporating M-mode measurement of wall thickening predicts an uneventful clinical course (Spes et al., 1999).

Computed tomographic angiography, although useful in detecting traditional atherosclerosis, has limitations in heart transplant recipients. The major drawbacks with the routine use of 16 or 64 slice multidetector CT in this population include the high heart rate of most heart transplant recipients (due to cardiac vagal denervation) that may compromise imaging quality, contrast-induced nephropathy and radiation. However, compared with 
ISHLT CAV 0 (not significant) No detectable angiographic lesion

$\mathrm{ISHLT} \mathrm{CAV}_{1}$ (Mild)

Angiographic left main (LM) $<50 \%$, or primary vessel with maximum lesion of $<70 \%$, or any branch stenosis $<70 \%$ (including diffuse narrowing) without allograft dysfunction

ISHLT CAV 2 (Moderate) Angiographic LM $<50 \%$; a single primary vessel $\geq 70 \%$ stenosis, or isolated branch stenosis $\geq 70 \%$ in branches of 2 systems, without allograft dysfunction

ISHLT CAV 3 (Severe)

Angiographic $\mathrm{LM} \geq 50 \%$, or $\geq 2$ primary vessels $\geq 70 \%$ stenosis, or isolated branch stenosis $\geq 70 \%$ in all 3 systems; or ISHLT CAV 1 or 2 with allograft dysfunction (defined as $\mathrm{LVEF} \leq 45 \%$, usually in the presence of regional wall motion abnormalities) or evidence of significant restrictive physiology (which is common but not specific)

Table 3. The International Society for Heart and Lung Transplantation Recommended Nomenclature for Cardiac Allograft Vasculopathy. 'Primary vessel' denotes the proximal and middle $33 \%$ of the LAD, circumflex, ramus and the dominant or co-dominant right coronary artery with the posterior descending and posterolateral branches. 'Secondary branch vessel' includes the distal 33\% of the primary vessels or any segment within a large septal perforator, diagonals and OM branches or any portion of a non-dominant RCA. Restrictive physiology is defined as symptomatic heart failure with echocardiographic $\mathrm{E}$ to A velocity ratio $>2$, shortened isovolumetric relaxation time $(<60 \mathrm{msec})$, shortened deceleration time $(<150 \mathrm{msec})$ or restrictive invasive hemodynamics (right atrial pressure $>12 \mathrm{mmHg}$, pulmonary capillary wedge pressure $>25 \mathrm{mmHg}$, cardiac index $<2 \mathrm{~L} / \mathrm{min} / \mathrm{m}^{2}$ )

IVUS, the sensitivity, specificity, positive and negative predictive values for the detection of CAV by dual source CT were $85 \%, 84 \%, 76 \%$, and 91\% respectively (Schepis et al., 2009). Magnetic resonance coronary angiography, at present, shows limited sensitivity for detecting CAV and positron emission tomography (PET) has not yet been well studied (Muehling et al., 2003).

Serum biomarkers provide important clues to molecular and structural changes within the transplanted heart. The role of inflammation has been demonstrated by the elaboration of inflammatory cytokines in patients with CAV. Elevated CRP levels have been shown to be associated with increased risk of developing $\mathrm{CAV}$, suggesting a link between systemic and local inflammation within the coronary artery of the transplanted heart (Arora et al., 2010; Raichlin et al., 2007). However, it is not clear if CRP is merely a marker or if it is involved in CAV pathogenesis. Persistently elevated troponin I levels after heart transplantation are associated with an increased risk of development of CAV (Labarrere et al., 2000). Elevated BNP has also been correlated with the development of CAV (Mehra et al., 2004b). BNP may be useful in combination with angiographic findings in predicting outcomes, with $50 \%$ of patients with high BNP levels and angiographic CAV experiencing cardiac death (Tsutsui $e t$ al., 2001). Biomarkers may hold predictive correlation, but are not used routinely for the evaluation of CAV. 


\section{Prevention and treatment}

Therapeutic options in CAV can be thought of in terms of prevention and treatment. Medical therapy aims to slow, halt, or even reverse the intimal proliferation, concentric luminal loss and arterial obliteration that characterize CAV. Preventive therapy targets traditional cardiac risk factors (diabetes mellitus, hyperlipidemia and hypertension) and aggressive treatment of rejection episodes. Rapidly progressive CAV within the first year after heart transplant strongly predicts all-cause mortality, myocardial infarction, and the subsequent development of angiographically severe CAV. Accordingly, prophylactic strategies must be implicated very early to induce significant improvement in long-term prognosis.

Statins have been associated with reduced progression of CAV, and routine administration of statins to all patients after transplant has clearly reduced the mortality and progression of the disease (Wenke et al., 2003). A meta-analysis based on the published results of three randomized clinical trials determined that the use of statins decreased 1-year mortality following heart transplantation from $17.1 \%$ to $5.4 \%$ (Mehra et al., 2004c). The introduction of routine anti-CMV drugs to all CMV seropositive patients (donor or recipient or both) for at least 3 months and in some centers up to 6 months has lowered the incidence of CMV infection and its impact on the graft. In a randomized study, patients receiving gancyclovir were significantly more likely to remain free of CAV for 5 years post transplant (Valantine et al., 1999).

There are small studies that suggest calcium channel blockers, such as diltiazem, are effective in slowing the progression of CAV (Schroeder et al., 1993). ACE inhibitors have been associated with plaque regression and improved survival for established CAV, however pre-emptive therapy with ACE inhibitors has unknown preventative effects (Bae et al., 2006). Currently, there is little definitive evidence to suggest that calcium channel blockers or ACE inhibitors are effective in reducing the incidence or slowing the progression of CAV.

Diabetes is common in cardiac transplant recipients and most heart transplant patients are markedly insulin resistant and demonstrate many of the features of compensatory hyperinsulinemia, including the atherogenic and proinflammatory profile of the metabolic syndrome (Potena L \& Valantine H, 2007). Patients with high plasma glucose or insulin concentrations after oral glucose intake have greater intimal thickness and are less likely to be free of CAV and have significantly lower survival during 5 years of follow up than patients with low glucose and insulin levels (Valantine et al., 2001). Specific therapies shown to be effective in correcting insulin resistance, such as the thiazolidinediones, offer potential new therapeutic targets for CAV prevention, however the clinical studies are lacking.

Owing to the diffuse nature of vasculopathy, conventional therapeutic approaches including percutaneous coronary intervention and coronary artery bypass grafting are optional only late in the course and are not always successful or even feasible.

Immunosuppression continues to represent the principal means of pharmacologic prophylaxis against and treatment of allograft vasculopathy, with the development and introduction of the proliferation signal inhibitors (PSI) sirolimus and everolimus representing the greatest advance achieved to-date in this field. PSI's are powerful immunosuppressant drugs that inhibit cellular proliferation and have shown the ability to 
reduce, and even reverse, coronary intimal growth in established CAV and reduce the incidence of CAV in de novo transplant patients through a variety of mechanisms, including a reduction in CMV infection and decreased rejection episodes. (Eisen et al., 2003; Keogh et al., 2004).

In a prospective multi-center randomized double blind control trial, patients who received everolimus, cyclosporine and steroids versus azathioprine, cyclosporine and steroids had a significant reduction in the incidence of CAV at 12 months (35.7\% versus $52.8 \%$ ), fewer grade $\geq 3 \mathrm{~A}$ cellular rejections (21.3\% versus $30.6 \%$ ) and CMV infection (12\% versus $41.4 \%$ ) (Eisen et al., 2003). Similar results were found with sirolimus (Keogh et al., 2004). The longterm results of both studies demonstrate a trend toward a lower incidence of severe vasculopathy in the group that is maintained on PSI with patients treated with everolimus having significantly lower rates of major cardiovascular events related to CAV compared to patients treated with azathioprine (7.9\% vs. 13.6\%) (Eisen et al., 2006; Keogh et al., 2007).

The available data suggest the efficacy of PSIs in reducing the incidence of CAV; however, up to $30-40 \%$ of patients in the clinical trials had to discontinue the PSI during the first year because of poor tolerability. Complications and side effects include bacterial and viral infections (17-30\%), oral ulcerations, pericardial effusions (up to $25 \%$ ) and pleural effusions (15-40\%), hematologic abnormalities including anemia and thrombocytopenia, impaired wound healing, acne, and pedal edema. Adverse events may be related to the dosing regimen (high vs. low dose) and timing (immediately post transplant vs. delayed introduction). A recent study with lower serum concentrations of everolimus $(3-8 \mathrm{ng} / \mathrm{mL})$ report a lower drop-out rate of $15 \%$ (Lehmukuhl et al., 2009). At this time, it remains unclear whether patients should be transitioned to a PSI-based immunosuppressant regimen once sternal healing has occurred.

In relation to the pharmacologic treatment of established CAV, aggressive control of traditional cardiac risk factors is important; however, the PSIs represent the most important advance. Studies in which patients with established CAV were switched to a PSI from MMF or azathioprine demonstrated a significant reduction in CAV-related adverse events (5\% vs. $25 \%$ ) including death, percutaneous coronary intervention (PCI), myocardial infarction, or angiographic progression of the disease 2 years following the transition and a reduction in plaque size compared to progression (Mancini et al., 2003; Segovia et al., 2004). Larger studies are needed to corroborate these initial findings; however, it is generally accepted practice that patients with established CAV are transitioned to PSI.

The treatment of established CAV represents a clinical challenge. Non-pharmacologic treatment includes $\mathrm{PCI}$, coronary artery bypass grafting (CABG), and retransplantation. Percutaneous and surgical revascularization is limited by the diffuse coronary involvement, the infrequency of focal lesions with suitable distal targets, and the high mortality rates with surgical intervention (up to 30-40\%) (Musci et al., 1998; Patel et al., 1997). PCI is associated with excellent short-term results, however is associated with high restenosis rates. With the advent of drug eluting stents, preliminary studies suggest much lower restenosis rates. (Lee et al., 2008). PCI remains a palliative therapy, as CAV is a diffuse and progressive disease process. It may be appropriate to perform PCI in patients with discrete focal lesions with abnormal graft function or evidence of stress-induced functional significance by stress imaging. Retransplantation is the only definitive therapy for CAV; however, survival is lower than after primary heart transplant and the probability of CAV in the retransplanted 
heart is higher than in de novo transplants (up to $50 \%$ at 3 years) (Musci et al., 1998; Srivastava et al., 2000). Re-transplantation is reserved for highly selected patients with CAV.

\section{Summary}

The development of CAV has been described as the Achilles heel of cardiac transplantation. The increased mortality observed in the years after the diagnosis of CAV reflects that fact that, at present, the management of these patients represents a clinical challenge. Diagnosis is heavily reliant on invasive testing and early diagnosis and preventive strategies are crucial, but remain ineffective in many cases. Statins, antihypertensive drugs, and anti-CMV agents have all demonstrated a modest beneficial reduction in CAV; however, the proliferation signal inhibitors represent the best prevention and treatment options available at this time. Current research focuses on identification of novel agents that are effective in preventing the development and progression of $\mathrm{CAV}$, and non-invasive techniques for $\mathrm{CAV}$ diagnosis.

\section{References}

Al-Khaldi A, Oyer PE, Robbins RC. (2006). Outcome analysis of donor gender in heart transplantation. Journal of Heart and Lung Transplantation, Vol. 25, No. 4, (February 2006), pp. 461-468, ISSN 1053-2498.

Arora S, Gunther A, Wennerblom B, Uelan T, Andreassen AK, Gude E, Endresen K, Geiran O, Wilhelmsen N, Andersen R, Aukrust P, Gullestad L. (2010). Systemic Markers of inflammation are associated with cardiac allograft vasculopathy and an increased intimal inflammatory component. American Journal of Transplantation, Vol. 10, No. 6, (June 2010), pp. 1428-1436, ISSN 1600-6135.

Bae JH, Rihal CS, Edwards BS, Kushwaha SS, Mathew V, Prasad A, Holmes DR Jr, Lerman A. (2006). Association of angiotensin-converting enzyme inhibitors and serum lipids with plaque regression in cardiac allograft vasculopathy. Transplantation, Vol 82, No. 8, (October 2006), pp. 1108-1111, ISSN 0041-1337.

Bieber CP, Stinson EB, Shumway NE, Payne R, Kosek J. (1970). Cardiac transplantation in man. VII. Cardiac allograft vasculopathy. Circulation, Vol. 41, No. 5, (January 1970), pp. 753-72, ISSN 0009-7322.

Briscoe DM , Yeung AC, Schoen FJ, Allred EN, Stavrakis G, Ganz P, Cotran RS, Pober JS, Schoen EL. (1995). Predictive value of inducible endothelial cell adhesion molecule expression for acute rejection of human cardiac allografts. Transplantation, Vol. 59, No. 2, (January 1995), pp. 204-211, ISSN 0041-1337.

Cohen O, De La Zerda DJ, Beygui R, Hekmat D, Laks H. (2007). Donor brain death mechanisms and outcomes after heart transplantation. Transplantation Proceedings, Vol. 39, No. 10, (December 2007), pp:2964-2969, ISSN 0041-1345.

Costanzo MR, Naftel DC, Pritzker MR, Hellman JK, Boehmer JP, Brozena SC, Dec WG, Ventura HO, Kirklin JK, Bourge RC, Miller LW. (1998). Heart transplant coronary artery disease detected by coronary angiography: a multi-institutional study of preoperative donor and recipient risk factors. Cardiac Transplant Research Database. The Journal of Heart and Lung Transplantation, Vol. 17, No. 8, (August 1998), pp744-753, ISSN 1053-2498. 
De Marco T, Dae M, Yuen-Green M, Kumar S, Sudhir K, Keith F, Amidon T, Rifkin C, Klinski C, Lau D, Botvinick E, Chatterjee K. (1995). Iodine-123 metaiodobenzylguanidine scintigraphic assessment of the transplanted human heart: evidence for late reinnervation. Journal of the American College of Cardiology, Vol. 25, No. 4, (March 1995), pp. 927-931, ISSN 0735-1097.

Derumeaux G, Redonnet M, Mouton-Schleifer D, Bessou JP, Cribier A, Saoudi N, Koning R, Soyer R, Letac B; VACOMED Research Group. (1995). Dobutamine stress echocardiography in orthotopic heart transplant recipients. Journal of the American College of Cardiology, Vol. 25, No. 7, (June 1995), pp. 1665-1672, ISSN 0735-1097.

Eisen HJ, Tuzcu EM, Dorent R, Kobashigawa J, Mancini D, Valantine-von Kaeppler HA, Starling RC, Sorensen K, Hummel M, Lind JM, Abeywickrama KH, Bernhardt P. (2003). Everolimus for the prevention of allograft rejection and vasculopathy in cardiac transplant recipients. New England Journal of Medicine, Vol. 349, No. 9, (August 2003), pp. 847-858, ISSN 0028-4793.

Eisen H, Yang X. (2006). The impact of proliferation signal inhibitors on the healthcare burden of major adverse cardiac events following heart transplantation. Transplantation, Vol. 82, No. 8 SUPPL, (October 2006), pp. S13-18, ISSN 0041-1337.

Ferri C, Properzi G, Tomassoni G, Santucci A, Desideri G, Giuliani AE, Cook DJ, McCarthy P, Young JB, Yamani MH. (2002). Patterns of myocardial endothelin-1 expression and outcome after cardiac transplantation. Circulation, Vol. 105, No. 15, (April 2002), pp. 1768-1771, ISSN 0009-7322.

Gasink LB, Blumberg EA, Localio AR, Desai SS, Israni AK, Lautenbach E. (2006). Hepatitis C virus seropositivity in organ donors and survival in heart transplant recipients. JAMA, Vol. 296, No. 15, (October 2006), pp. 1843-1850, ISSN 0098-7484

Haji SA, Avery RK, Yamani MH, Tuzcu EM, Crowe TD, Cook DJ, Mawhorter SD, Hobbs R, Young JB, Smedira N, Starling RC. (2006). Donor or recipient hepatitis B seropositivity is associated with allograft vasculopathy. Journal of Heart and Lung Transplantation, Vol. 25, No. 3, (March 2006), pp. 294-297, ISSN 1053-2498.

Haji SA, Starling RC, Avery RK, Mawhorter S, Tuzcu EM, Schoenhagen P, Cook DJ, Ratliff NB, McCarthy PM, Young JB, Yamani MH. (2004). Donor hepatitis-C seropositivity is an independent risk factor for the development of accelerated coronary vasculopathy and predicts outcome after cardiac transplantation. The Journal of Heart and Lung Transplantation, Vol. 23, No. 3, (March 2004), pp. 277-283, ISSN 10532498.

Hollenberg M, Klein LW, Parrillo JE, Scherer M, Burns D, Tamburro P, Oberoi M, Johson MR, Costanzo MR. (2001). Coronary endothelial dysfunction after heart transplantation predicts allograft vasculopathy and cardiac death. Circulation, Vol. 104, No. 25, (2001), pp. 3091-3096, ISSN 0009-7322.

Hosenpud JD, Streblow DN, Kreklywich C, Yin Q, De La Melena VT, Corless CL, Smith PA, Brakebill C, Cook JW, Vink C, Bruggeman CA, Nelson JA, Orloff SL. (2003). Cytomegalovirus-mediated upregulation of chemokine expression correlates with the acceleration of chronic rejection in rat heart transplant. Journal of Virology, Vol. 77, No. 3, (February 2003), pp. 2182-2194, ISSN 0022-538X.

Itagaki BK, Kobashigawa JA, Wu GW, Patel JK, Kawano MA, Kittleson MM, Fishbein MC. (2007). Widespread fibrosis of myocardial and adjacent tissues causing restrictive 
cardiac physiology in patients needing re-do heart transplant. Proceedings of the International Society of Heart and Lung Transplantation, San Francisco, April 2007.

Jimenez J, Kapadia SR, Yamani MH, Platt L, Hobbs RE, Rincon G, Botts-Silverman C, Starling R, Young JB, Nissen SE, Tuzcu M. (2001). Cellular rejection and rate of progression of transplant vasculopathy: A 3-year serial intravascular ultrasound study. Journal of Heart and Lung Transplantation, Vol. 20, No. 4, (April 2001), pp. 393398, ISSN 1053-2498.

Kapadia SR, Ziada KM, L'Allier PL, Crowe TD, Rincon G, Hobbs RE, Bott-Silverman C, Young JB, Nissen SE, Tuzcu EM. (2000). Intravascular ultrasound imaging after cardiac transplantation: advantage of multivessel imaging. The Journal of Heart and Lung Transplantation, Vol. 19, No. 2, (February 2000), pp. 167-172, ISSN 1053-2498.

Keogh A, Richardson M, Ruygrok P, Spratt P, Galbraith A, O'Driscoll G, Macdonald P, Esmore D, Muller D, Faddy S. (2004). Sirolimus in de novo heart transplant recipients reduces acute rejection and prevents coronary artery disease at 2 years: a randomized clinical trial. Circulation, Vol. 110, No. 17, (October 2004), pp. 26942700, ISSN 0009-7322.

Keogh A, Richardson M, Ruygrok P, Macdonald P, Schneider L, O'Driscoll G, Galbraith A. (2007). Sirolimus vs. azathioprine from the time of heart transplantation: 65 month follow-up for vascular (MACE) and malignant events. Proceedings of the International Society of Heart and Lung Transplantation, San Francisco, April 2007.

Keogl AM, Valantine HA, Hunt SA, Schroeder J, McIntosh N, Oyer P, Stinson E. (1992). Impact of proximal or midvessel discrete coronary artery stenosis on survival after heart transplanation. The Journal of Heart and Lung Transplantation, Vol. 11, (1992), pp. 892-901.

Kobashigawa JA, Tobis JM, Starling RC, Tuzcu EM, Smith AL, Valantine HA, Yeung AC, Mehra MR, Anzai H, Oeser BT, Abeywickrama KH, Murphy J, Cretin N. (2005). Multicenter intravascular ultrasound validation study among heart transplant recipients: outcomes after five years. Journal of the American College of Cardiology, Vol. 45, No. 9, (May 2005), pp. 1532-1537, ISSN 0735-1097.

Koskinen PK. (1993). The association of the induction of vascular cell adhesion molecule-1 with cytomegalovirus antigenemia in human heart allografts. Transplantation, Vol. 56, No. 5, (November 1993), pp. 1103-1108, ISSN 0041-1337.

Labarrere CA, Nelson DR, Cox CJ, Pitts D, Kirlin P, Halbrook H. (2000). Cardiac-specific troponin I levels and risk of coronary artery disease and graft failure following heart transplantation. Journal of the American Medical Association, Vol. 284, No. 4, (July 2000), pp. 457-464, ISSN 0098-7484.

Lee MS, Kobashigawa J, Tobis J. (2008). Comparison of percutaneous coronary intervention with bare metal and drug eluting stents for cardiac allograft vasculopathy. Journal of the American College of Cardiology: Cardiovascular Interventions, Vol. 1, No. 6, (December 2008), pp. 710-715, ISSN 1936-8798.2282

Lehmukuhl H, Arizon J, Vigano M, Almenar L, Gerosa G, Maccherini M, Varnous S, Musumeci F, Hexham J, Mange K, Livi U. (2009). Everolimus with reduced cyclosporine versus MMF with standard cyclosporine in de novo heart transplant recipients. Transplantation, Vol. 88, No. 1, (July 2009), pp. 115-122, ISSN 0041-1337.

Li H, Tanaka K, Anzai H, Oeser B, Lai D, Kobashigawa JA, Tobis JM. (2006). Influence of pre-existing donor atherosclerosis on the development of cardiac allograft 
vasculopathy and outcomes in heart transplant recipients. Journal of the American College of Cardiology, Vol. 47, No. 12, (June 2006), pp. 2470-2476, ISSN 0735-1097.

Libby P, Tanaka H. (1994). The pathogenesis of coronary arteriosclerosis ("chronic rejection") in transplanted hearts. Clinical Transplantation, Vol. 3, No. 2 (June 1994), pp. 313-318, ISSN 0902-0063.

Luyt CE, Drobinski G, Dorent R, Ghossoub J, Collet J, Choussat R, Dalby M Thomas D, Gandjbakhch I. (2003). Prognosis of moderate coronary artery lesions in heart transplant patients. The Journal of Heart and Lung Transplantation, Vol. 22, No. 2, (February 2003), pp. 130-136, ISSN 1053-2498.

Mancini D, Pinney S, Burkhoff D, LaManca J, Itescu S, Burke E, Edwards N, Oz M, Marks A. (2003). Use of rapamycin slows progression of cardiac transplantation vasculopathy. Circulation, Vol. 108, No. 1, (July 2003), pp. 48-53, ISSN 0009-7322.

Martinez-Dolz L, Almenar L, Martinez-Ortiz L, Arnau MA, Chamorro C, Moro J, Osa A, Rueda J, Garcia C, Palencia M. (2005). Predictive factors for development of diabetes mellitus post-heart transplant. Transplantation Proceedings, Vol. 37, No. 9, (November 2005), pp. 4064-4066, ISSN 0041-1345.

Mehra MR, Crespo-Leiro MG, Dipchand A, Ensminger SM, Hiemann NE, Kobashigawa JA, Madsen J, Parameshwar J, Starling RC, Uber PA. (2010). International Society for Heart and Lung Transplantation working formulation of a standardized nomenclature for cardiac allograft vasculopathy - 2010. The Journal of Heart and Lung Transplantation, Vol. 29, No. 7, (July 2010), pp. 717-727, ISSN 1053-2498.

Mehra MR \& Raval NY. (2004c). Metaanalysis of statins and survival in de novo cardiac transplantation. Transplantation Proceedings, Vol. 36, No. 5, (June 2004), pp. 15391541, ISSN 0041-1345.

Mehra MR, Uber PA, Potluri S, Ventura HO, Scott RL, Park MH. (2004b). Usefulness of an elevated B-type natriuretic peptide to predict allograft failure, cardiac allograft vasculopathy, and survival after heart transplantation. American Journal of Cardiology, Vol. 94, No. 4, (August 2004), pp. 454-458, ISSN 0002-9149.

Mehra MR, Uber PA, Ventura HO, Scott RL, Park MH. (2004a). The impact of mode of donor brain death on cardiac allograft vasculopathy. Journal of the American College of Cardiology, Vol. 43, No. 5, (March 2004), pp. 806-810, ISSN 0735-1097.

Mehra MR, Ventura HO, Stapleton DD, Smart FW, Collins TC, Ramee SR. (1995). Presence of severe intimal thickening by intravascular ultrasonography predicts cardiac events in cardiac allograft vasculopathy. The Journal of Heart and Lung Transplantation, Vol. 14, No. 4, (July-August 1995), pp. 632-639, ISSN 1053-2498.

Michaels PJ, Espejo ML, Kobashigawa J, Alejos JC, Burch C, Takemoto S, Reed EF, Fishbein MC. (2003). Humoral rejection in cardiac transplantation: risk factors, hemodynamic consequences and relationship to transplant coronary artery disease. Journal of Heart and Lung Transplantation, Vol. 22, No. 1, (January 2003), pp. 58-69, ISSN 1053-2498.

Muehling OM, Wilke NM, Panse P, Jerosch-Herold M, Wilson BV, Wilson RF, Miller LW. (2003). Reduced myocardial perfusion reserve and transmural perfusion gradient in heart transplant arteriopathy assessed by magnetic resonance imaging. Journal of the American College of Cardiology, Vol. 42, No. 6, (September 2003), pp.1054-1060, ISSN 0735-1097. 
Musci M, Loebe M, Wellnhofer E, Meyer R, Pasic M, Hummel M, Bocksch W, Grauhan O, Weng Y, Hetzer R. (1998). Coronary angioplasty, bypass surgery, and retransplantation in cardiac transplant patients with graft coronary artery disease. The Journal of Thoracic and Cardiovascular Surgery, Vol. 46, No. 5, (October 1998), pp. 268-274, ISSN 0171-6425.

Nagji AS, Hranjec T, Swenson BR, Kern JA, Bergin JD, Jones DR, Kron IL, Lau CL, Ailawadi G. (2010). Donor age is associated with chronic allograft vasculopathy after adult heart transplantation: implications for donor allocation. Annals of Thoracic Surgery, Vol. 90, No. 1, (July 2010), pp. 168-175, ISSN 0003-4975.

Neish AS, Loh E, Schoen FJ. (1992). Myocardial changes in cardiac transplant-associated coronary arteriosclerosis: potential for timely diagnosis. Journal of the American College of Cardiology, Vol. 19, No. 3, (March 1992), pp.586-592, ISSN 0735-1097.

Nissen S. (2001). Coronary angiography and intravascular ultrasound. American Journal of Cardiology, Vol. 87, No. 4A, (February 2001), pp. 15A-20A, ISSN 0002-9149.

Novitzky D, Rose AG, Cooper DK. (1988). Injury of myocardial conduction tissue and coronary artery smooth muscle following brain death in the baboon. Transplantation, Vol. 45, No. 5, (May 1988), pp. 964-966, ISSN 0041-1337.

Pardo Mindan FJ, Panizo A, Lozano MD, Herreros J, Mejia S. (1997). Role of endomyocardial biopsy in the diagnosis of chronic rejection in human heart transplantation. Clinical Transplantation, Vol. 11, No. 5, (October 1997), pp. 426-431, ISSN 0902-0063.

Patel VS, Radovancevic B, Springer W, Frazier OH, Massin E, Benrey J, Kadipasaoglu K, Cooley DA. (2007). Revascularization procedures in patients with transplant coronary artery disease. European Journal of Cardiothoracic Surgery, Vol. 11, No. 5, (May 1997), pp. 895-901, ISSN 1010-7940.

Pflugfelder PW, Boughner DR, Rudas L, Kostuk WJ. (1993). Enhanced detection of cardiac allograft arterial disease with intracoronary ultrasonographic imaging. American Heart Journal, Vol. 125, No. 6, (June 1993), pp. 1583-1591, ISSN 0002-8703.

Potena L \& Valantine H. (2007). Cardiac allograft vasculopathy and insulin resistance - hope for new therapeutic targets. Endocrinology and Metabolism Clinics of North America, Vol. 36, No. 4, (December 2007), pp. 965-981, ISSN 0889-8529.

Raichlin E, Edwards BS, Kremers WK, Clavell AL, Rodeheffer RJ, Frantz RP, Pereira NL, Daly RC, McGregor CG, Lerman A, Kushwaha SS. (2009). Acute cellular rejection and the subsequent development of allograft vasculopathy after cardiac transplantation. Journal of Heart and Lung Transplantation, Vol. 28, No. 4, (April 2009), pp. 320-327, ISSN 1053-2498.

Raichlin ER, McConnell JP, Lerman A, Kremers WK, Edwards BS, Kushwaha SS, Clavell AL, Rodeheffer RJ, Frantz RP. (2007). Systemic inflammation and metabolic syndrome in cardiac allograft vasculopathy. Journal of Heart and Lung Transplantation, Vol. 26, No. 8. (August 2007), pp. 826-833, ISSN 1053-2498.

Rickenbacher PR, Pinto FJ, Lewis NP, Hunt SA, Alderman EL, Schroeder JS, Stinson EB, Brown BW, Valantine HA. (1995). Prognostic importance of intimal thickness as measured by intracoronary ultrasound after cardiac transplantation. Circulation, Vol. 92, No. 12, (December 1995), pp. 3445-3452, ISSN 0009-7322.

Sanchez Lazaro IJ, Bonet LA, Lopez JM, Lacuesta ES, Martinez-Dolz L, Ramon-Llin J,A Lalaguna LA, Perez OC, Martinez VO, Fuentes FB, Sanz AS. (2008). Influence of traditional cardiovascular risk factors in the recipient on the development of 
cardiac allograft vasculopathy after heart transplantation. Transplantation Proceedings, Vol. 40, No. 9, (November 2008), pp. 3056 - 3057, ISSN 0041-1345.

Schepis T, Achenbach S, Weyand M, Raum P, Marwan M, Pflederer T, Daniel WB, Tandler R, Kondruweit M, Ropers D. (2009). Comparison of dual source computed tomography versus intravascular ultrasound for evaluation of coronary arteries at least one year after cardiac transplantation. American Journal of Cardiology, Vol. 104, No. 10, (November 2009), pp. 1351-1356, ISSN 0002-9149.

Schoreder JS, Gao SZ, Alderman EL, Hunt SA, Johnstone I, Boothroyd DB, Wiederhold V, Stinson EB. (1993). A preliminary study of diltiazem in the prevention of coronary artery disease in heart-transplant recipients. New England of Journal of Medicine, Vol. 328, No. 3, (January 1993), pp. 164-170, ISSN 0028-4793.

Segel LD, Von Haag DW, Zhang J, Follette DM. (2002). Selective overexpression of inflammatory molecules in hearts from brain-dead rats. Journal of Heart and Lung Transplantation, Vol. 21, No. 7, July 2002), pp. 804-811, ISSN 1053-2498.

Segovia J, Aloinso-Pulpon L, Ortiz P, Jimenez-Mazuecos J, Alfonso F, Escaned J, HernandezAntolin R, Macaya C. (2004). Rapastat: evaluation of the role of oral sirolimus in the treatment of established graft vessel disease. A prospective, randomized intravascular ultrasound study. Proceedings from the International Society of Heart and Lung Transplantation, San Francisco, April 2004.

Spes CH, Klauss V, Mudra H, Schnaack SD, Tammen AR, Rieber J, Siebert U, Henneke KH, Uberfuhr P, Reichart B, Theisen K, Angermann CE. (1999). Diagnostic and prognostic value of serial dobutamine stress echocardiography for noninvasive assessment of cardiac allograft vasculopathy: a comparison with coronary angiography and intravascular ultrasound. Circulation, Vol. 100, No. 5, (August 1999), pp. 509-515, ISSN 0009-7322.

Srivastava R, Keck BM, Bennett LE, Hosenpud JD. (2000). The results of cardiac retransplantation: an analysis of the Joint International Society for Heart and Lung Transplantation/United Network for Organ Sharing Thoracic Registry. Transplantation, Vol. 70, No. 4, pp. 606-612, ISSN 0041-1337.

Stork S, Behr T, Birk M, Uberfuhr P, Klauss V, Spes C, Angermann C. (2006). Assessment of cardiac allograft vasculopathy late after heart transplantation: when is coronary angiography necessary? The Journal of Heart and Lung Transplantation, Vol. 25, No. 9, (September 2006), pp. 1103-1108, ISSN 1053-2498.

Takada M, Nadeau KC, Hancock WW, Mackenzie HS, Shaw GD, Waaga AM, Chandraker A, Sayegh MH, Tilney NL. (1998). Effects of explosive brain death on cytokine activation of peripheral organs in the rat. Transplantation, Vol. 65, No. 12, (June 1998), pp. 1533-1542, ISSN 0041-1337.

Taylor DO, Edwards LB, Boucek MM, Trulock EP, Waltz, DA, Keck BM, Hertz MI. (2006). Registry of the International Society for Heart and Lung Transplantation: twentythird official adult heart transplantation report - 2006. The Journal of Heart and Lung Transplantation, Vol. 25, No. 8, (August 2006), pp. 869-879, ISSN 1053-2498.

Taylor DO , Edwards LB, Boucek MM, Trulock EP, Aurora P, Christie J, Dobbels F, Rahmel AO, Keck BM, Hertz MI. (2007). Registry of the International Society for Heart and Lung Transplantation: twenty-fourth official heart transplant report -2007. Journal of Heart and Lung Transplantation, Vol. 26, No. 8, (August 2007), pp. 769-781, ISSN 1053-2498. 
Tona F, Caforio A, Montisci R, Gambino A, Angelini A, Ruscazio M, toscano G, Feltrin F, Ramondo A, Gerosa G, Iliceto S. (2006). Coronary Flow Velocity Pattern and Coronary Flow Reserve by Contrast-Enhanced Transthoracic echocardiography predict long-term outcome in heart transplantation. Circulation, Vol. 114, No. I Suppl, (July 2006), pp. I49-I55, ISSN 0009-7322.

Tsutsui H, Ziada KM, Schoenhagen P, Iyisoy A, Magyar WA, Crowe TD, Klingensmith JD, Vince DG, Rincon G, Hobbs RE, Yamagishi M, Nissen SE, Tuzcu EM. (2001). Lumen loss in transplant coronary artery disease is a biphasic process involving early intimal thickening and late constrictive remodeling: results from a 5-year serial intravascular ultrasound study. Circulation, Vol. 104, No. 6, pp. 653-657, ISSN 0009-7322.

Tuzcu EM, Kapadia SR, Sachar R, Ziada KM, Crowe TD, Feng J, Magyar WA, Hobbs RE, Starling RC, Young JB, McCarthy P, Nissen SE. (2005). Intravascular ultrasound evidence of angiographically silent progression in coronary atherosclerosis predicts long-term morbidity and mortality after cardiac transplantation. Journal of the American College of Cardiology, Vol. 45, No. 9, (May 2005), pp. 1538-1542, ISSN 07351097.

Valantine HA, Gao SZ, Menon SG, Renlund DG, Hunt SA, Oyer P, Stinson EB, Brown BW, Merigan TC, Schroeder JS. (1999). Impact of prophylactic immediate posttransplant ganciclovir on development of transplant atherosclerosis: A post hoc analysis of a randomized, placebo-controlled study. Circulation, Vol. 100, No. 1, (July 1999), pp. 61-66, ISSN 0009-7322.

Valantine H, Rickenbacker P, Kemna M, Hunt S, Chen Y, Reaven G, Stinson E. (2001). Metabolic abnormalities characteristic of dysmetabolic syndrome predict the development of transplant coronary artery disease: a prospective study. Circulation, Vol. 103, No. 17, (May 2001), pp. 2144-2152, ISSN 0009-7322.

Van Dorp WT, Jonges E, Bruggeman CA, Daha MR, Van Es LA, Van Der Woude FJ. (1989). Direct induction of MHC class I, but not class II, expression on endothelial cells by cytomegalovirus infection. Transplantation, Vol. 48, No. 3, (September 1989), pp. 469-472, ISSN 0041-1337.

We GW, Kobashigawa JA, Fishbein MC, Patel JK, Kittleson MM, Reed EF, Kiyosaki KK, Ardehali A. (2009). Asymptomatic antibody-mediated rejection after heart transplantation predicts poor outcomes. Journal of Heart and Lung Transplantation, Vol. 28, No. 5, (May 2009), pp. 417-422, ISSN 1053-2498.

Weill D. (2001). Role of cytomegalovirus in cardiac allograft vasculopathy. Transplant Infectious Disease, Vol. 3, Supplement 2, (2001), pp. 44-48, ISSN 1398-2273.

Weis, M, Kledal TN, Lin KY, Panchal SN, Gao SZ, Valantine HA, Mocarski ES, Cooke JP. (2004). Cytomegalovirus infection impairs the nitric oxide synthase pathway: role of asymmetric dimethylarginine in transplant arteriosclerosis. Circulation, Vol. 109, No. 4, (February 2004), pp. 500-505, ISSN 0009-7322.

Wenke K, Meiser B, Thiery J, Nagel D, von Scheidt W, Krobot K, Steinbeck G, Seidel D, Reichart B. (2003). Simvastatin initiated early after heart transplantation: 8-year prospective experience. Circulation, Vol. 107, No. 1, (January 2003), pp. 93-97, ISSN 0009-7322.

Yamasaki M, Sakurai R, Hirohata A, Honda Y, Bonneau HN, Luikart H, Yock PG, Fitzgerald PJ, Yeung AC, Valantine HA, Fearon WF. (2011). Impact of donor-transmitted 
atherosclerosis on early cardiac allograft vasculopathy: new findings by threedimensional intravascular ultrasound analysis. Transplantation, Vol. 91, No. 12, (June 2011), pp. 1406-1411, ISSN 0041-1337. 


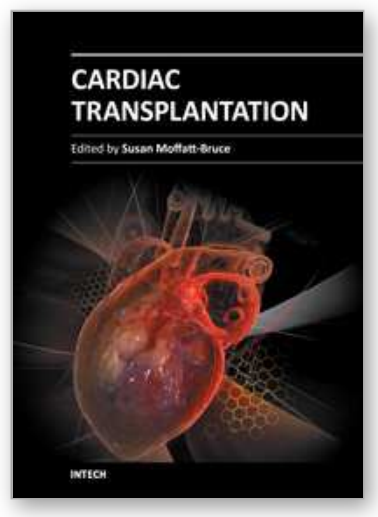

\author{
Cardiac Transplantation \\ Edited by Dr. Susan Moffatt-Bruce
}

ISBN 978-953-51-0000-3

Hard cover, 154 pages

Publisher InTech

Published online 10, February, 2012

Published in print edition February, 2012

We are truly in an era of change not only in terms of technology but in the type of patient we are caring for. That is why I feel this book is exciting in that it presents the team approach to the transplant patient. I am confident that the pioneers of cardiac transplantation would be pleased with our response to challenges in healthcare today and be pleased with the final product.

\title{
How to reference
}

In order to correctly reference this scholarly work, feel free to copy and paste the following:

Brian Clarke and Kiran Khush (2012). Cardiac Allograft Vasculopathy: An Ongoing Challenge in the Care of Heart Transplant Recipients, Cardiac Transplantation, Dr. Susan Moffatt-Bruce (Ed.), ISBN: 978-953-51-00003, InTech, Available from: http://www.intechopen.com/books/cardiac-transplantation/cardiac-allograftvasculopathy-an-ongoing-challenge-in-the-care-of-heart-transplant-recipients

\section{INTECH}

open science | open minds

\author{
InTech Europe \\ University Campus STeP Ri \\ Slavka Krautzeka 83/A \\ 51000 Rijeka, Croatia \\ Phone: +385 (51) 770447 \\ Fax: +385 (51) 686166 \\ www.intechopen.com
}

\author{
InTech China \\ Unit 405, Office Block, Hotel Equatorial Shanghai \\ No.65, Yan An Road (West), Shanghai, 200040, China \\ 中国上海市延安西路65号上海国际贵都大饭店办公楼 405 单元 \\ Phone: +86-21-62489820 \\ Fax: +86-21-62489821
}


(C) 2012 The Author(s). Licensee IntechOpen. This is an open access article distributed under the terms of the Creative Commons Attribution 3.0 License, which permits unrestricted use, distribution, and reproduction in any medium, provided the original work is properly cited. 